\title{
A Cryptic Plasmid from Shigella sonnei
}

\author{
By J. E. CROFT, P. L. BERGQUIST* AND D. LANE \\ Department of Cell Biology, University of Auckland, Auckland, New Zealand
}

(Received 21 April 1982; revised 23 November 1982)

\begin{abstract}
pNZ500 is a $1.5 \mathrm{~kb}$ cryptic plasmid from a Shigella sonnei isolate. It was introduced into Escherichia coli by cotransformation, where it is maintained at about 30 copies per chromosome equivalent. Hybridization studies show that pNZ500 exhibits a high level of sequence similarity to other $1.5 \mathrm{~kb}$ plasmids found in different $S$. sonnei isolates but shares no homology with larger $S$. sonnei plasmids. pNZ500 shares a small degree of sequence homology with pBR322 and with pAC184. The homology with pBR322 is restricted to sequences close to the ori-bom region of this plasmid. Nevertheless, pNZ500 maintenance in $E$. coli is not dependent on DNA polymerase I activity, and does depend on continuing protein synthesis. pNZ500 encodes two polypeptide gene products whose monomer molecular weights are 24500 and 18000 . The examination of host cells for the expression of possible plasmid phenotypes revealed no differences between cells bearing pNZ500 and plasmidless cells.
\end{abstract}

\section{INTRODUCTION}

Many bacterial species harbour plasmids which are termed 'cryptic' because they confer no obvious phenotype on their host cells (Jansz et al., 1969; Rush et al., 1969; Christiansen et al., 1973; Mayer et al., 1974; Moller et al., 1978; Mann \& Rao, 1979; van Embden et al., 1980b). Indeed, plasmids of this type constitute a majority in some bacterial groups (Moller et al., 1978). In general, cryptic plasmids are small, stably inherited, and maintained at high copy number: a well-studied example is the p15A plasmid found in E. coli 15 (Cozzarelli et al., 1968). However, large cryptic plasmids have been observed (Spratt et al., 1973; Datta et al., 1979).

It is not uncommon to find multiple species of cryptic plasmids in bacteria isolated from natural environments (Stahly et ai., 1978; González et al., 1980). We have reported previously a large number of plasmids in clinical isolates of Shigella sonnei (Jamieson et al., 1979). Individual isolates have, in addition to self-transmissible and drug-resistance plasmids, up to eight cryptic plasmids which can be distinguished on the basis of their mobilities in agarose gels. These cryptic plasmids range in size from 1.5 to $7.2 \mathrm{~kb}$ but only one plasmid was found to be common to all strains studied. This $1.5 \mathrm{~kb}$ plasmid was shown to be mobilized efficiently by a co-resident self-transmissible plasmid in crosses with laboratory strains of Escherichia coli. In this paper we present data on the replication properties and gene products of this $1.5 \mathrm{~kb}$ plasmid (pNZ500) from $S$. sonnei.

\section{METHODS}

Bacterial strains and plasmids are listed in Table 1. The following materials and methods have been described previously: media (Bergquist \& Adelberg, 1972), partial purification (cleared lysates) and complete purification (dye-buoyant density centrifugation) of plasmid DNA, restriction endonuclease digestion, T4 DNA ligase joining, and transformation (Lane \& Gardner, 1979), blotting of DNA to DBM cellulose (Wahl et al., 1979), preparation of radioactive probe DNA (Rigby et al., 1977), hybridization (Bergquist et al., 1982), copy-number determination (Bergquist et al., 1981), and purification of DNA from low melting point (Seaplaque) agarose (Langridge et al., 1980).

Abbreviation: DBM cellulose, diazobenzyloxymethyl cellulose. 


\section{Table 1. Bacterial strains and plasmids}

\begin{tabular}{|c|c|}
\hline Bacterial strain & Genotype \\
\hline \multicolumn{2}{|l|}{ Escherichia coli $\mathrm{K} 12$} \\
\hline C600 & $\begin{array}{l}\mathrm{F}^{-} \text {thi-1 thr-1 leu-6 } \\
\text { lacY1 supE44 tonA21 }\end{array}$ \\
\hline P678-54 & $\begin{array}{l}\mathrm{F}^{-} \text {thi-I thr-I leu- } 6 \\
\text { lac } Y 1 \text { gal minA } \min B\end{array}$ \\
\hline PB 1907 & $\mathrm{~F}^{-}$polAl nal \\
\hline PBI 132 & $\begin{array}{l}\mathrm{F}^{-} \text {galTl2 lacZ32 thr } \\
\text { recAl }\end{array}$ \\
\hline PB1761 & $\mathrm{F}^{-}$pro his trp lac nal \\
\hline
\end{tabular}

Shigella sonnei

SH-1, 7, 16, 20, 28 Prototrophic
$46 \mathrm{MDal}\left(\mathrm{Tc}^{\mathrm{r}} \mathrm{Tra}^{+}\right), 24 \cdot 5 \mathrm{MDal}$
$\left(\mathrm{Tra}^{+}\right), 1.0 \mathrm{MDal}$ plasmids

All carry 1 MDal plasmid, plus $46,24 \cdot 5,5 \cdot 5,1 \cdot 9,1 \cdot 6$ and 1.2 MDal plasmids in various combinations

$\begin{array}{cc}\begin{array}{c}\text { Other } \\ \text { properties* }\end{array} & \begin{array}{c}\text { Size } \\ (\mathrm{kb})\end{array} \\ \text { Mob }^{+} & 1.5 \\ \text { rep-ts } & 16 \\ & 4.36 \\ & 5.4 \\ & 3.9 \\ & 16 \\ \text { Tra }^{+} & 125 \\ & 6.9 \\ & 6.9 \\ & 6.5\end{array}$

Source/reference

L. Caro

H. Adler

S. Falkow

This laboratory

SH34, Jamieson et al. (1979)

See Jamieson et al. (1979)

\section{Source}

Jamieson et al. (1979)

This laboratory

Bolivar et al. (1977)

Bolivar (1978)

Chang \& Cohen (1978)

Lovett \& Helinski (1976)

This laboratory

This paper

This paper

This paper

* Abbreviations: $\mathrm{Km}^{\mathrm{R}}$, kanamycin resistance; $\mathrm{Ap}^{\mathrm{R}}$, ampicillin resistance; $\mathrm{Cm}^{\mathrm{R}}$, chloramphenicol resistance; $\mathrm{Tra}^{+}$, transfer proficient; $\mathrm{Mob}^{+}$, able to be mobilized by a transfer-proficient plasmid carried by the same strain; rep-ts, temperature-sensitive for replication.

$\dagger$ Kanamycin-resistance fragment from pML21 joined to a temperature-sensitive replication region from a mutant $\mathrm{F}^{\prime}$-gal ${ }^{+}$at their EcoRI sites (described in Gardner et al., 1980).

$\ddagger$ Hybrid plasmids constructed by joining pBR325 and pNZ500 at their EcoRI sites.

Incompatibility testing. Transformants were screened for the presence of the resident plasmid marker by replicaplating. Ten transformant colonies were pooled, resuspended, diluted into L-broth and grown for 22 generations. Culture samples were diluted and spread on L-agar and the resulting colonies replica-plated on to $\mathrm{L}$ agar containing ampicillin, or tetracycline, or both.

Transposition of $\operatorname{Tn} 3$ to $p N Z 500$. R386:: Tn 3 was introduced by conjugation into $\mathrm{C} 600$ carrying pNZ500. The strain carrying both plasmids was grown in L-broth at $30^{\circ} \mathrm{C}$ to maximize $\operatorname{Tn} 3$ transposition (Kretschmer \& Cohen, 1979). Plasmid DNA was purified and used to transform C600 to ampicillin-resistance on L-agar containing $400 \mu \mathrm{g}$ ampicillin $\mathrm{ml}^{-1}$ : at this concentration ampicillin kills cells containing only the low copy-number R386: : Tn 3 plasmid. Restriction endonuclease analyses of 12 pNZ500 : : Tn 3 plasmids extracted from the transformants revealed that $\operatorname{Tn} 3$ had inserted at six different sites within a region of approximately $0 \cdot 4 \mathrm{~kb}$ (Fig. $4 a$ ). The clustering of sites could reflect either a high frequency of $\operatorname{Tn} 3$ target sequences in this region or the necessity of sequences outside this region for plasmid maintenance.

Construction of $p$ NZ500-pBR325 hybrid plasmids. Hybrid plasmids were constructed by cloning pNZ500 via its single EcoRI site into the EcoRI site of the chloramphenicol transacetylase gene of pBR325. The orientation of pNZ500 with respect to pBR325 was determined by digestions with the restriction endonuclease HpaII (Fig. 4 b). Hybrid plasmids containing pNZ500 in either orientation were obtained (see Fig. $4 b$ ).

Identification of polypeptides in minicells. Minicell polypeptide analysis followed the basic method of Roozen et al. (1971). The minicell-producing strain, P678-54, containing pNZ500 or other plasmids, was grown to stationary phase in L-broth. Minicells were purified by three cycles of sucrose gradient centrifugation $(10-30 \%$, w/v; minicell : viable cell ratio $\left.>10^{6}\right)$, resuspended in minimal medium $(56 / 2 ;$ Bergquist \& Adelberg, 1972) containing $15 \%(\mathrm{v} / \mathrm{v})$ glycerol and stored at $-76^{\circ} \mathrm{C} .2 \times 10^{9}$ minicells were incubated in $2 \mathrm{ml}$ medium $-56 / 2$ containing $5 \%$ (w/v) Difco methionine-assay medium, $0.5 \mu \mathrm{g}$ thiamin $\mathrm{ml}^{-1}, 1 \%(\mathrm{w} / \mathrm{v})$ glucose - for $10 \mathrm{~min}$ at $37^{\circ} \mathrm{C}$, then $40 \mu \mathrm{Ci}$ of [ ${ }^{35}$ S]methionine $\left(890 \mathrm{Ci} \mathrm{mol}^{-1}, 3 \cdot 3 \times 10^{7} \mathrm{MBq} \mathrm{mol}^{-1}\right.$; Amersham) were added for a further $30 \mathrm{~min}$. The minicells 


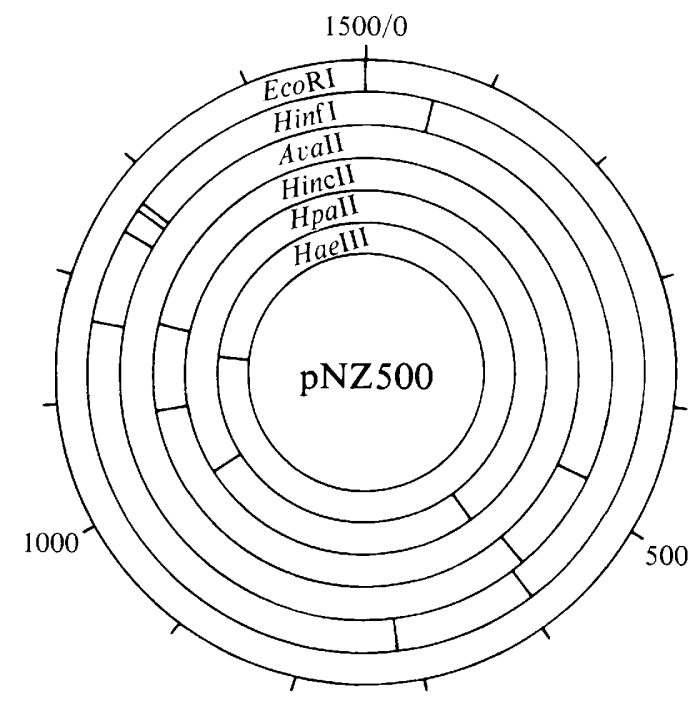

Fig. 1. Restriction endonuclease cleavage map of pNZ500. The EcoRI site is taken as the reference point $(1500 / 0)$ and distances (bp) are marked clockwise from this point. For the enzymes shown, all the sites needed to account for the fragment patterns seen in $1.5-1.8 \%$ agarose and $10 \%$ polyacrylamide gels have been mapped. pNZ500 also contains cleavage sites, as yet unmapped, for HaeII ( 3 sites), AluI ( $>6$ sites), HhaI ( $>7$ sites), TaqI ( $>2$ sites) and $H p a \mathrm{I}$ ( $>4$ sites), but it contains no sites recognized by PstI, BamHI, KpnI, HindIII or XhoI.

were centrifuged, resuspended in $2 \%(\mathrm{w} / \mathrm{v}) \mathrm{SDS}, 0.05 \%$ bromophenol blue, $0.0625 \mathrm{M}-\mathrm{Tris} / \mathrm{HCl} \mathrm{pH} 6 \cdot 8$, and incubated at $95^{\circ} \mathrm{C}$ for $2 \mathrm{~min}$. Samples containing $10^{4}-10^{5}$ c.p.m. were subjected to electrophoresis in SDS-polyacrylamide $(11 \%$, w/v) slab gels (Lugtenberg et al., 1975) at $180 \mathrm{~V}$ for $6 \mathrm{~h}$. PPO was precipitated into the gels (Bonner \& Laskey, 1974), which were then dried and exposed to X-ray film with intensifying screens at $-70^{\circ} \mathrm{C}$ for 3-7 d.

Mapping of restriction endonuclease sites on pNZ500. Purified pNZ500, or restriction fragments extracted from low melting point agarose (Langridge et al., 1980), were digested with restriction endonucleases alone or in combination, and the fragments were electrophoresed together with molecular weight standards on $1.8 \%(\mathrm{w} / \mathrm{v})$ agarose gels. This procedure served to locate the sites of HincII, HaeIII, HpaII and AvaII cleavage relative to the EcoRI site. The method of Smith \& Birnstiel (1976) was used to map the Hinf I sites. EcoRI-cleaved pNZ500 was incubated with $\left[\alpha^{-32} \mathrm{P}\right] \mathrm{dATP}$ and the large fragment of DNA polymerase I to label the $3^{\prime}$-termini. The labelled DNA was digested with HaeIII and the two fragments purified from low melting point agarose. Each fragment was then partially digested with $\operatorname{Hinf} \mathrm{I}$ and the digestion products electrophoresed on $8 \%(\mathrm{w} / \mathrm{v})$ polyacrylamide gels. The gels were exposed to X-ray film, and the sizes of the terminally-labelled partial digestion products were measured relative to standards and used to calculate the distances between Hinf I cleavage sites.

Enzymes. Hinf I, HpaII, HaeIII, HincII, AvaII, DNA polymerase I large fragment, and T4 DNA ligase, were purchased from New England Biolabs. Other restriction endonucleases were prepared in this laboratory by the method of Greene et al. (1978). Escherichia coli DNA polymerase I was purchased from Boehringer.

\section{RESULTS}

\section{Restriction enzyme map of pNZ500}

A combination of single and double digestions by EcoRI, HpaII, HaeIII, HincII, Hinf I and AvalI, together with the terminal-labelling procedure, were used to construct the restriction enzyme map of pNZ500 shown in Fig. 1. PstI, BamHI, KpnI, HindIII and XhoI did not cleave pNZ500 DNA under conditions expected to give complete digestion.

\section{pNZ500 is maintained independently of other plasmids}

To study the properties of pNZ500, it was desirable to establish it in a strain which carried no other plasmids. We introduced pNZ500 into E. coli K12 C600 because no Shigella strain free of plasmids was available to us. All of the experiments described below were carried out with $E$. coli strains. 
pNZ500 carried no known selectable marker. Therefore, we used the cotransformation technique of Kretschmer et al. (1975) to select competent cells, and transformants were subsequently screened for the presence of the unselected plasmid. pNZ500 DNA from the $E$. coli exconjugant PB1761 (Jamieson et al., 1979) was extracted from a low melting point agarose gel and mixed with pNZ049, a mutant mini-F plasmid carrying kanamycin resistance which is temperature-sensitive for replication (Gardner et al., 1980), in the molar ratio $1000 \mathrm{pNZ} 500: 1 \mathrm{pNZ}$ 049. The mixture was used to transform strain C600 to kanamycin resistance at $32^{\circ} \mathrm{C}$. Four of the $22 \mathrm{Km}^{\mathrm{R}}$ transformants analysed by agarose gel electrophoresis of cleared lysates contained a $1.5 \mathrm{~kb}$ plasmid in addition to $\mathrm{pNZ049}$. Growth of the transformants at $42{ }^{\circ} \mathrm{C}$ resulted in simultaneous loss of kanamycin resistance and of the pNZ049 plasmid. Restriction endonuclease and hybridization analyses (data not shown) demonstrated that the $1.5 \mathrm{~kb}$ plasmid is pNZ500. Hence pNZ500 must be an autonomous replicon which requires no function encoded by other Shigella or E. coli plasmids to replicate.

\section{Sequence relationships of pNZ500 with other plasmids}

Partially purified Shigella plasmid DNA (in cleared lysates) was subjected to agarose gel electrophoresis (Fig. $2 a$ ), transferred to DBM filters, and incubated with denatured ${ }^{32}$ P-labelled pNZ500 DNA. After hybridization and washing the filter was exposed to X-ray film to give the radioautograph shown in Fig. $2(b)$. pNZ500 hybridizes with the $1.5 \mathrm{~kb}$ plasmids present in all the Shigella strains, but hybridization with other Shigella plasmids was not detected. Therefore, under the hybridization conditions used $\left(0.3 \mathrm{M}-\mathrm{NaCl}, 50 \%\right.$ formamide, $\left.42{ }^{\circ} \mathrm{C}\right) \mathrm{pNZ} 500$ shows no significant degree of sequence homology with any of the larger plasmids in its original Shigella host. Densitometry of the radioautograph and of the photograph of the stained gel, using exposures in which film response is linear, gave an approximate estimate of the extent of annealing of pNZ500 to the $1.5 \mathrm{~kb}$ plasmids relative to the annealing to pNZ500 itself. The $1.5 \mathrm{~kb}$ plasmids bound the pNZ500 probe DNA with about the same efficiency as pNZ500 itself, and it is likely that each of these plasmids is identical to pNZ500.

Low levels of hybridization were observed when a similar experiment was performed with purified DNA of the p15A-related plasmid, pACYC184, and with pMB9 and pBR322 (Fig. 2c, d). After a correction to the densitometric data for molecular weight differences among the plasmids the amount of probe bound to pACYC184 and to pMB9 was $2 \pm 1 \%$ of that which binds to an equimolar amount of pNZ500 (detailed data not shown). Also shown in this figure are results for pLG500, a cryptic plasmid similar to pNZ500 (Broome-Smith, 1980): this plasmid showed a high degree of homology with pNZ500, binding $70 \pm 20 \%$ as much probe DNA as pNZ500 itself.

Hybridization between pNZ500 and fragments of the pMB1-derived plasmid pBR322 was used to locate the region of sequence homology between these plasmids. Hybridization with Avall-digested pBR322 demonstrated that homology with pNZ500 is restricted to the $1743 \mathrm{bp}$ fragment (nucleotides 1759-3502; Sutcliffe, 1978) known to encompass the replication origin and the region required for mobilization (data not shown). A more precise estimate of the region of homology was provided by $A l u \mathrm{I}, H$ paII, and HhaI digests of pBR322. pNZ500 hybridized with $A l u I$ fragment 6 (nucleotides 2135-2416; Sutcliffe, 1978), HpaII fragment 2 (nucleotides 2154-2681) and HhaI fragments 11 and 5 (2210-2351 and 2384-2654), as shown in Fig. 2(e,f,g).

Annealing to the HhaI fragments 28 or 29 was not observed since these fragments ( 33 and $30 \mathrm{bp}$ ) ran off the gel. It is possible that most of the homology is within one of these fragments since the amount of radioactivity associated with fragments 5 and 11 is very low relative to the amount bound to $A l u \mathrm{I}$ fragment 6 and $\mathrm{HpaII}$ fragment 2. These results suggest that the sequence homology is located close to the bom site (2207-2263) of pBR322 (Covarrubias et al., 1981).

\section{pNZ500 replication requires protein synthesis but not DNA polymerase I acitivity}

pNZ500 is a multicopy plasmid: dye-buoyant density centrifugation of radioactively-labelled DNA showed that pNZ500 has a copy number of 32 per chromosome equivalent in cells grown in minimal/glucose/Casamino acids medium (data not shown). Since the hybridization data (Fig. 2) suggested that pNZ500 shares sequence homology with the origin region of pBR322, it 
appeared possible that its replication would show similarities to that of pBR322. The latter plasmid requires DNA polymerase I activity for replication, but can continue to replicate for several hours in the absence of protein synthesis whereupon it becomes amplified relative to chromosomal DNA (Clewell, 1972).

Dependence of pNZ500 replication on continuing protein synthesis was tested in the following way. An L-broth culture of $E$. coli C600 carrying pNZ500 and pNZ049 was divided into two portions; one was incubated with no additions while the other was incubated with chloramphenicol $\left(200 \mu \mathrm{g} \mathrm{ml}^{-1}\right)$ for $8 \mathrm{~h}$. Cleared lysates prepared from both cultures were electrophoresed in an agarose gel which was then stained with ethidium bromide. Comparison of the fluorescence intensities of the plasmid bands (Fig. 3) revealed that the relative quantities of the two plasmids were the same in both cultures. Similarly, no chloramphenicol-induced amplification of pNZ500 was observed either for cells containing pNZ500 alone, or for cultures grown in minimal medium. Hence pNZ500 replication shows the same, relatively strict, dependence on continuing protein synthesis as does the mini-F plasmid.

Dependence of pNZ500 on DNA polymerase I activity was tested in two ways. First, two pNZ500:: Tn3 derivatives (pNZ503 and pNZ504; Fig. 4a) were used to transform a pol $^{+}$strain, $\mathrm{C} 600$, and a pol strain, PB1907, and the transformation frequencies were determined. DNA polymerase I-dependent (pBR322) and independent (pML31) plasmids served as controls. The results (Table $2 a$ ) show that the pNZ500:: Tn3 plasmids transform the pol strain at frequencies similar to that exhibited by pML31 whereas the polymerase I-dependent pBR322 yielded no transformants. The pNZ500::Tn3 plasmids remained stable in the pol strain through subsequent subcultures. Hence pNZ500 does not require DNA polymerase I for replication, at least in the quantities needed by pBR322.

Second, pNZ500-pBR325 hybrids which contained the component replicons in either orientation (pNZ501 and pNZ502; see Methods and Fig. 4b), were used in a similar transformation experiment (data included in Table $2 a$ ). No transformants (fewer than 5 per $\mu$ g DNA) were obtained, a result which conflicts with the conclusions drawn from the first experiment. The simplest explanation is that the EcoRI site used in the construction of pNZ501 and pNZ502 lies in a region essential for maintenance of pNZ500. It may be significant that $\operatorname{Tn} 3$ insertions are found in only a limited region of the pNZ500 genome, suggesting that the remainder of the plasmid, including the EcoRI site, may be required for maintenance.

The lack of DNA polymerase I dependence and failure to be amplified in cells treated with chloramphenicol show that the replication properties of pNZ500 are quite distinct from those of pACYC184 and pBR322. This conclusion was reinforced by the observation that pNZ504 is compatible with pACYC184 and with pMB9 from which pBR322 is derived (Table $2 b$ ). The inherent instability of pACYC184 (Table $2 b$, line iii; see also Meacock \& Cohen, 1980) accounts for the apparent weak incompatibility of pNZ504 and pACYC184 (Table $2 b$, line ii).

\section{pNZ500 encodes two polypeptides}

The ability of cells harbouring pNZ500 to produce plasmid-specified polypeptides was investigated by the minicell technique. Minicells purified from strain P678-54 carrying pNZ500, pNZ500:: Tn3 (pNZ503), pMB8 : :Tn3 (RSF1050) and pMB8 were analysed. pNZ500 minicells contain two polypeptides of molecular weight $24500(24 \cdot 5 \mathrm{~K})$ and $18000(18 \mathrm{~K})$ which are not present in plasmidless minicells (Fig. $5 a, b$ ). The amounts of the pNZ500 polypeptides are much lower than those of the major Tn 3 polypeptides, and thus the pNZ500 gene products are seen only as faint bands (arrowed) in Fig. 5(b). The same result was obtained for cells labelled with ${ }^{1+} \mathrm{C}$-labelled amino acids (data not shown). Products with molecular weights less than about 14000 would not have been seen in this experiment since they would have run off the gel under the conditions employed for separation $(11 \%$ w/v acrylamide $)$.

The $18 \mathrm{~K}$ polypeptide is present in pNZ503 (Fig. $5 c$ ) but the $24.5 \mathrm{~K}$ polypeptide, which has a mobility intermediate between the mobilities of the two similarly-sized Tn3 polypeptides (Fig. $5 c, d$ ), is not seen. This observation suggests that the coding sequence for the $24.5 \mathrm{~K}$ gene product is interrupted by the Tn3 insertion in pNZ503. 

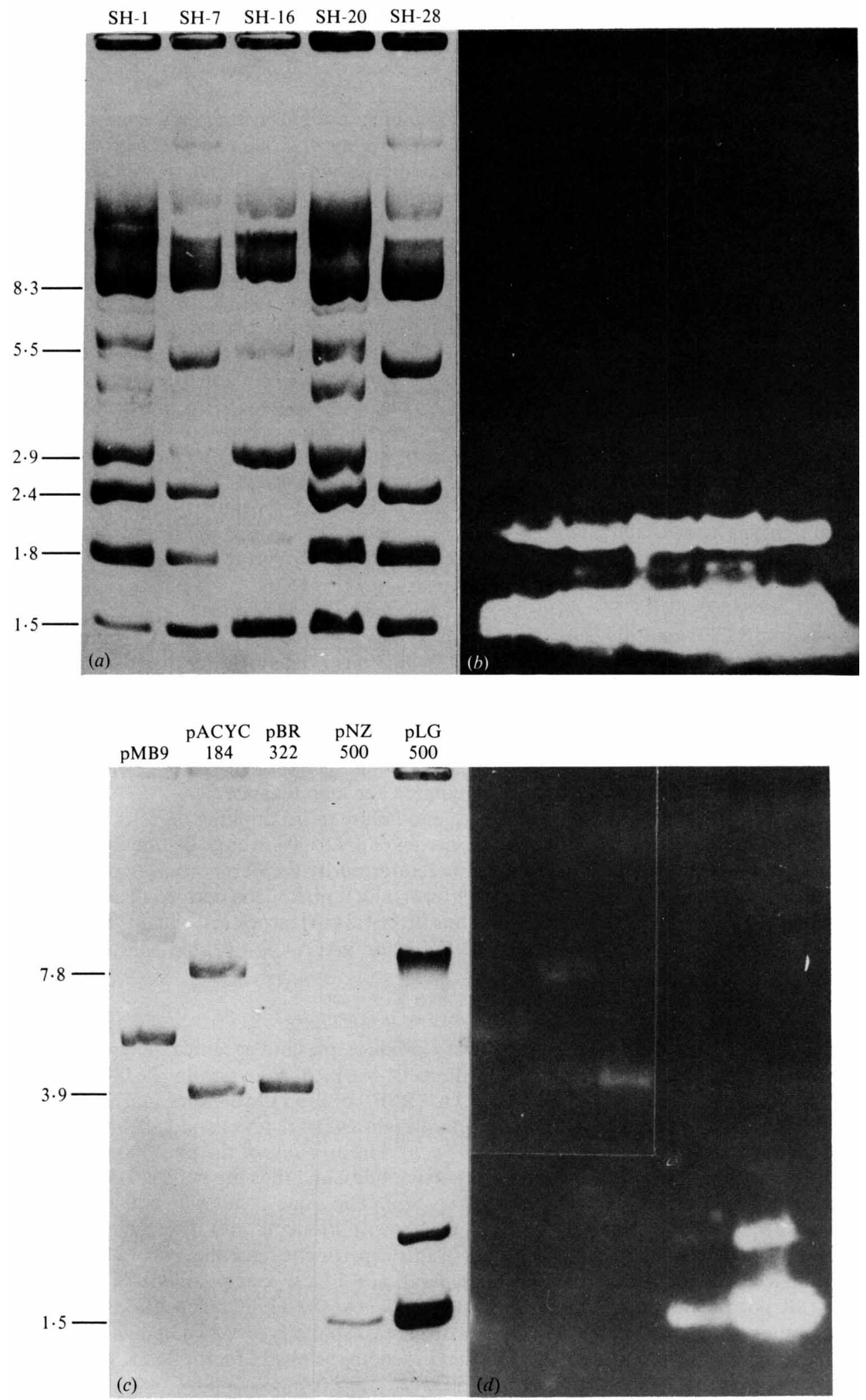


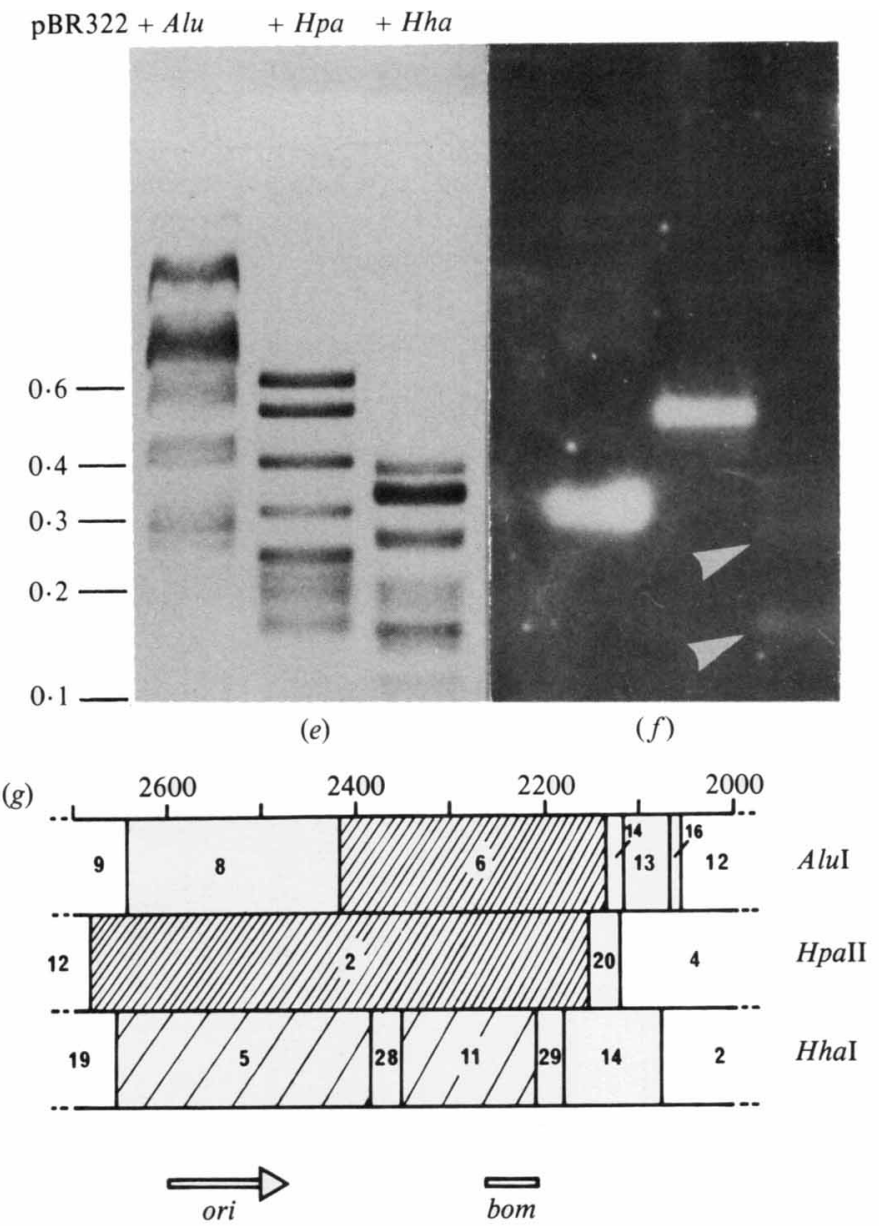

Fig. 2. Nucleotide sequence relationships of pNZ500 with other plasmids. Plasmids or restriction fragments were electrophoresed in agarose gels and were then transferred to DBM paper and incubated with denatured ${ }^{32}$ P-labelled pNZ500 DNA as described in the text. $(a, c, e)$ Agarose gels; $(b$, $d, f)$ radioautographs. Numbers at the left of $a, c, e$ are the sizes $(\mathrm{kb})$ of plasmids or fragments.

$(a, b)$ (see facing page) Shigella sonnei plasmids, in cleared lysates, electrophoresed in $0.8 \%$ agarose. The upper band showing homology is open-circular $1.5 \mathrm{~kb}$ plasmid DNA, which can be seen in the $\mathrm{SH} 16$ plasmid profile.

$(c, d)$ (see facing page) Various small plasmids ( $\mathrm{CsCl} /$ ethidium bromide purified) and $\mathrm{pLG} 500$ (cleared lysate) electrophoresed in $0.8 \%$ agarose. Most of the molecules in the pACYC184 preparation used here were dimers.

$(e, f)$ pBR322 digested with restriction enzymes and electrophoresed in $1.6 \%$ agarose. Annealing of pNZ500 with Hha fragments 5 and 11 (white arrows) yields only very faint bands, indicating weak homology.

(g) Regions of pBR322 having sequence homology with pNZ500. EZIZZ, strong homology; ZZZ, weak homology of fragments produced by cleavage (vertical lines) with the restriction endonucleases shown at the right. The numbers at the top are base-pair co-ordinates of pBR322.

\section{Search for host properties specified by pNZ500}

The presence of pNZ500 in strain C600 did not confer resistance to any of nine commonlyused antibiotics nor to eight common colicins, and the strain did not produce a colicin. C600 and C600 carrying pNZ500 showed identical sensitivities to growth in the presence of either SDS or sodium deoxycholate, and to UV irradiation. Their growth rates, average cell size, average DNA content per cell and reversion frequencies for chromosomal mutations were identical. 


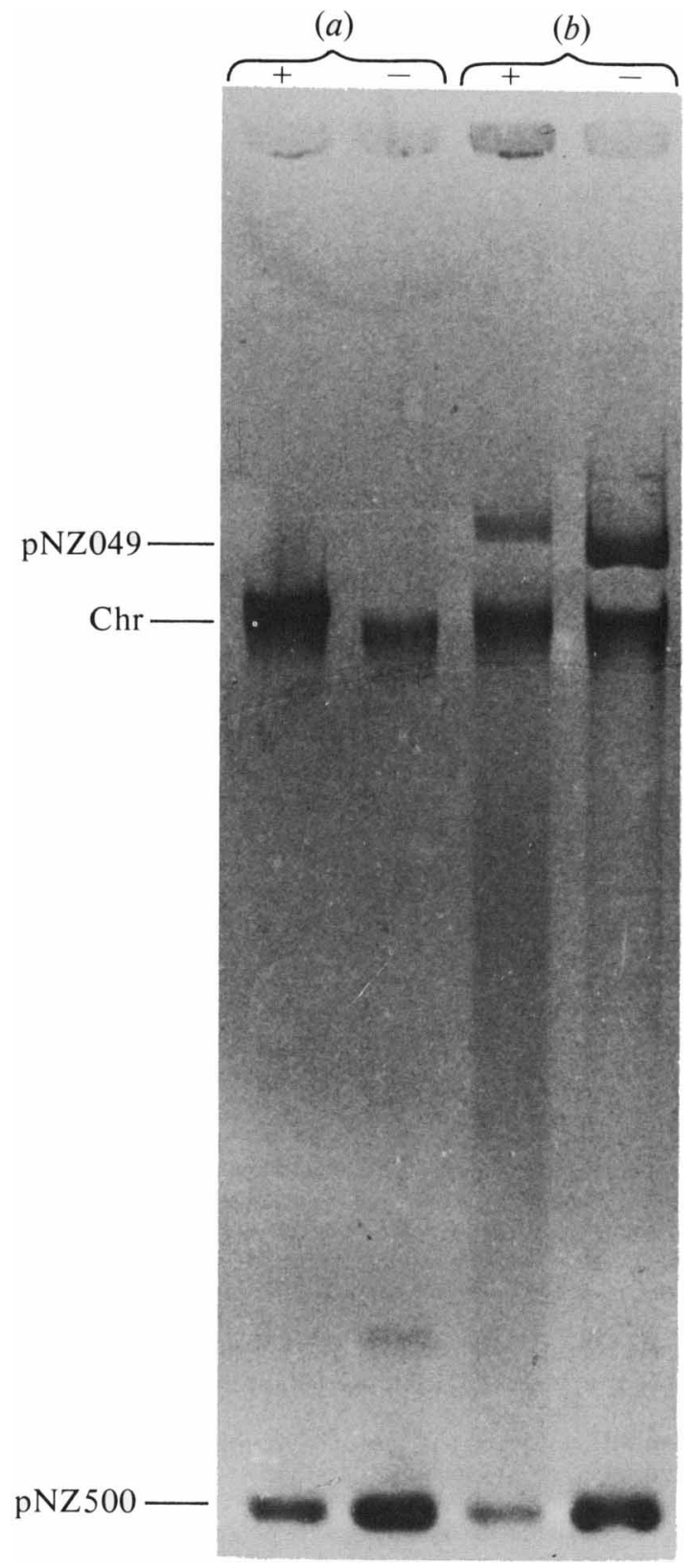

Fig. 3. pNZ500 levels in normal and chloramphenicol-treated cells. Cleared lysates, prepared from cultures of $(a) C 600 / \mathrm{pNZ} 500$ or $(b) \mathrm{C} 600 / \mathrm{pNZ} 500$, pNZ049 which had been treated $(+)$ or left untreated $(-)$ with chloramphenicol, were phenol-extracted. Nucleic acids were precipitated with ethanol, redissolved and treated with RNAase A. Samples were electrophoresed in $1.0 \%$ agarose gels, and bands visualized after staining with ethidium bromide. Samples equivalent to equal volumes of culture were applied to the gels; this resulted in over-loading for the untreated sample so that the pNZ049 bands have different mobilities. Chr, chromosomal DNA in the cleared lysates. 


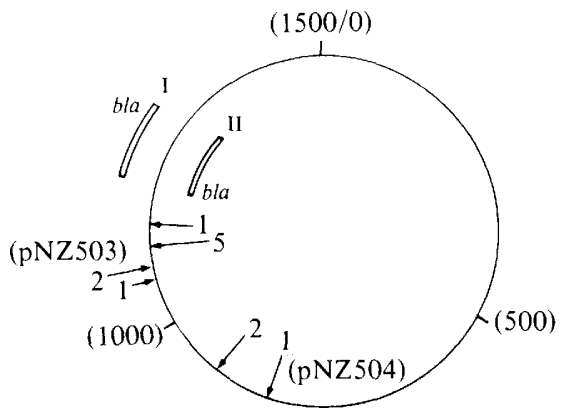

(a)

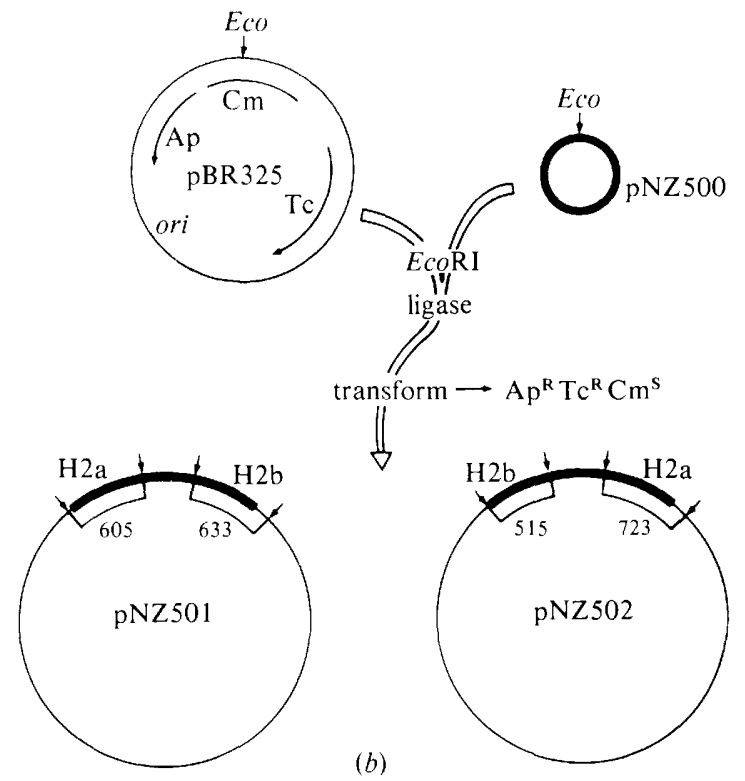

Fig. 4. Transposition and cloned derivatives of $\mathrm{pNZ500.} \mathrm{(a)} \mathrm{pNZ500} \mathrm{derivatives} \mathrm{containing} \mathrm{Tn} 3$ were selected on the basis of resistance to high concentrations of ampicillin, as outlined in Methods. The site and orientation of $\operatorname{Tn} 3$ insertion for 12 derivative plasmids are shown with arrows. Numbers adjacent to arrows refer to the number of plasmid isolates found to have Tn3 inserted at each position. pNZ503 and pNZ504 are indicated next to their Tn3 insertion sites. For Tn3 in orientation I (arrows outside circle) the bla $\left(\mathrm{Ap}^{\mathrm{R}}\right)$ gene is at the clockwise end of the transposon, for orientation II (arrows inside circle) it is at the counterclockwise end. Numbers in parentheses are base-pair co-ordinates of pNZ500.

(b) pNZ500 was cut with EcoRI and inserted at the Eco site of pBR325. The orientation of the inserted pNZ500 was determined by measuring the sizes of the novel HpaII fragments created in formation of the hybrid plasmid. Arrows show relevant HpaII sites. Numbers inside the circle are the lengths of the novel fragments (bp). $\mathrm{H} 2 \mathrm{a}$ and $\mathrm{H} 2 \mathrm{~b}$ refer respectively to the longer and shorter HpaIIEcoRI intervals in pNZ500. Of eight plasmids analysed, three were like pNZ501, five were like pNZ502.

Table 2. Replication properties of pNZ500

(a) Transformation of polA and polA ${ }^{+}$strains with pNZ500 : Tn3

No. of transformants $(\mu \mathrm{g} \text { DNA })^{-1}$

DNA

pBR322
pML31
pNZ503
pNZ504
pNZ501
pNZ502
pBR325

$\overbrace{\mathrm{C} 600(\text { polA }})^{\mathrm{PB} 1907(\text { polAl) }}$

$1.3 \times 10^{6}$
$1.9 \times 10^{5}$
$1.1 \times 10^{5}$
$1.0 \times 10^{5}$
$9.5 \times 10^{5}$
$1.2 \times 10^{6}$
$8.5 \times 10^{5}$

$$
\begin{aligned}
& <10 \\
2.7 & \times 10^{3} \\
5.4 & \times 10^{3} \\
2.4 & \times 10^{2} \\
& <5 \\
& <5 \\
& <5
\end{aligned}
$$

(b) Incompatibility of $\mathrm{pNZ} 500^{*}$

$\begin{array}{ccccc}\text { Entering } & \text { Resident } & \text { Both } & \text { Neither } & \\ 0 & 0 & 100 & 0 & (771) \\ 19 & 0 & 81 & 0 & (433) \\ - & 94 & - & 6 & (376) \\ 0 & 1 & 99 & 0 & (161)\end{array}$

pMB9/PB1132
pACYC184/PB1132
pACYC184/PB1132
pNZ504/PB 1132

pACYC $184 / \mathrm{PB} 1132$
pNZ504/PB 1132

* Incompatibility results are presented as the percentage of cells containing the entering plasmid, the resident, or both. Total numbers of cells examined are given in parentheses. 


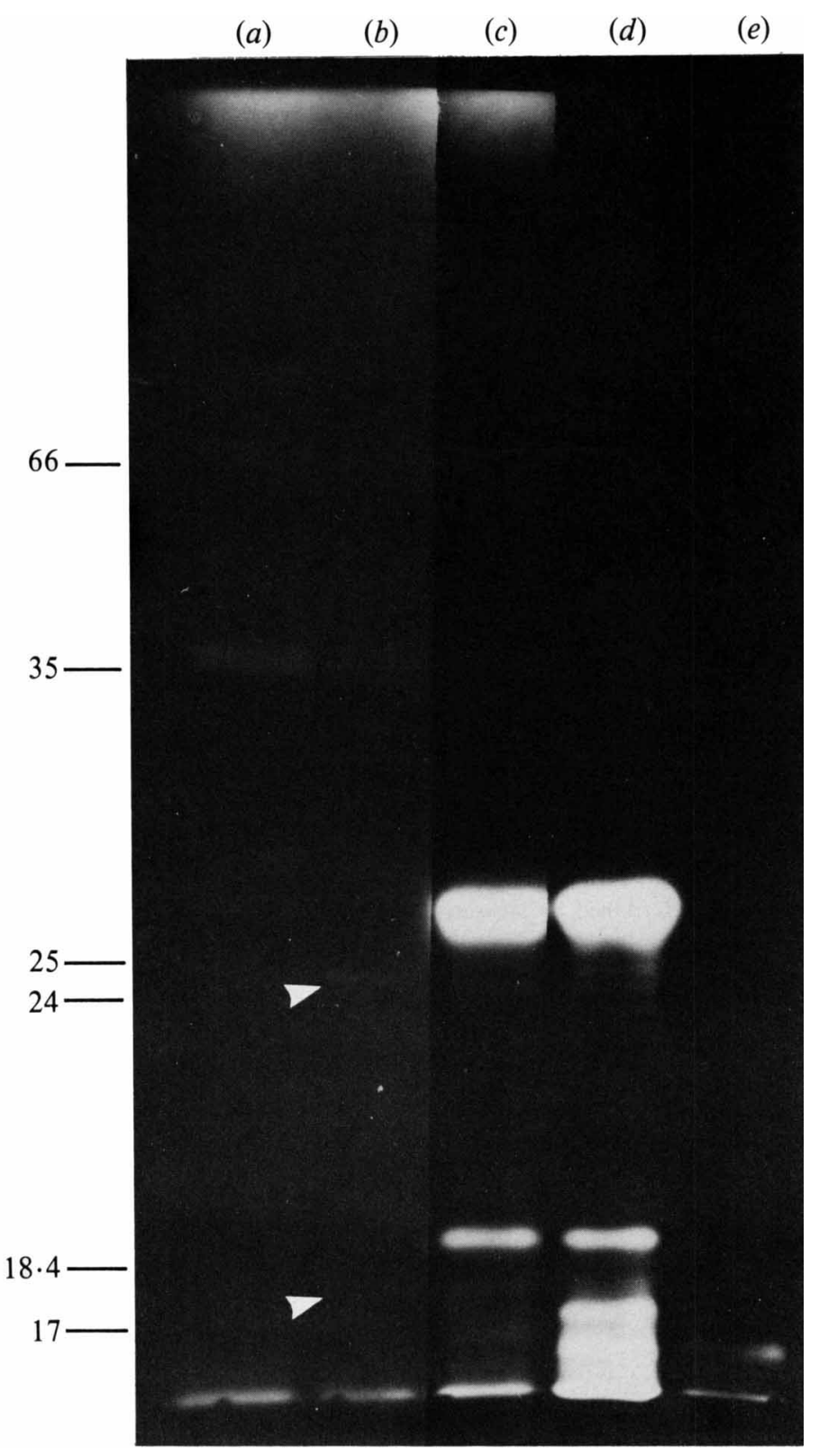

Fig. 5. Polypeptides encoded by pNZ500 and synthesized in minicells. [ ${ }^{35}$ S]methionine-labelled polypepticles made by minicells containing $(a)$ no plasmid, $(b)$ pNZ500, $(c)$ pNZ503 (pNZ500:: Tn 3 ), $(d)$ pMB8::Tn3, or (e) pMB8 were electrophoresed in an SDS-polyacrylamide gel and the bands detected by fluorography. Standard proteins, whose molecular sizes (in kilodaltons) are shown at the left, were electrophoresed in the same gel and their mobilities determined after Coomassie blue staining. Arrows indicate the positions of polypeptides synthesized in minicells containing pNZ500 but not in plasmidless minicells. pMB8:: Tn3 (track $d$ ) and pMB8 (track $e$ ) were included as control samples to identify the Tn3-specific proteins. In preparing the figure, different photographic exposures have been used to make visible each of the relevant bands. 
Neither strain was found to produce heat-stable or heat-labile enterotoxins, or Vero-cell cytotoxins (Konowalchuk et al., 1977). Neither strain was able to ferment raffinose, a property conferrred on certain bacteria by a plasmid-borne gene linked to the K88 surface antigen determinant (Smith \& Parsell, 1975). Colonization factor antigens and serum-resistance levels were not examined.

Thus no phenotype can yet be ascribed to pNZ500 other than the ability to replicate and the capacity for being mobilized during bacterial mating (Jamieson et al., 1979).

\section{DISCUSSION}

The $S$. sonnei cryptic plasmid, pNZ500, is physically very similar to a plasmid (pLG500) found in a natural E. coli isolate (Broome-Smith, 1980). This E. coli plasmid is approximately the same size as pNZ500. The two plasmids share extensive homology (Fig. $2 d$ ) and exhibit similar cleavage patterns for the restriction enzymes HaeII, HaeIII and HpaII. However, differences between the Hhal cleavage patterns suggest that the plasmids are not identical (J. Croft, unpublished data).

Broome-Smith (1980) demonstrated that mobilization of pLG500 by R64drd 11 requires the presence of ColEl or ColK. The Col plasmids provide a function which appears to cause the nicking of pLG500 DNA (at its bom site) during the mobilization process. In addition, the presence of the Col plasmids results in most of the pLG500 DNA adopting a relaxed circular form during normal growth of the host strain. In the work reported here, we have concentrated on aspects other than mobilization, and we have not attempted to test the effect of Col plasmids on the mobilization and intracellular forms of pNZ500. Nevertheless the studies of Jamieson $e t$ al. (1979) demonstrated that mobilization of pNZ500 could be effected in the absence of Col plasmids, and that either of two self-transmissible $S$. sonnei plasmids could provide the functions necessary for mobilization. Further studies of these plasmids should include a direct comparison of their mobilization properties.

The preliminary comparison of pNZ500 with small, multicopy E. coli plasmids presented here suggests that pNZ500 shares sequence similarities with these plasmids only in a short region near the ori and bom sites of pBR322. The homology is not within the ori site itself, which is found in $A l u \mathrm{I}$ fragment 8, nor is it confined to the bom site, which is within $H$ haI fragment 11 (Covarrubias et al., 1981). Rather, the data suggest that it lies between these sites. Therefore, its significance is unclear. This sequence homology is probably shared with pACYC184, since pBR322 and p15A share extensive sequence similarities in this region (Bird, 1981).

A part from the high copy number of pNZ500 (also shown by pLG500; Broome-Smith, 1980), the replication characteristics of this plasmid appear to be quite different from those of p15A and the ColE1-like plasmid pBR322. The latter plasmids are dependent on DNA polymerase I activity, but independent of continuing protein synthesis, i.e. they continue to replicate in the presence of chloramphenicol: pNZ500 replication is independent of DNA polymerase I and dependent on protein synthesis. The observation that $\operatorname{Tn} 3$ insertions were obtained within only a limited region of $\mathrm{pNZ} 500$ suggests that $\mathrm{pNZ} 500$ replication requires a greater amount of DNA than the 400-500 bp needed for ColE1 replication (Oka et al., 1979). It is possible that pNZ500, unlike ColE1, requires a plasmid-encoded protein for replication.

The two polypeptide gene products of pNZ500 require about $1100 \mathrm{bp}$ of coding sequence (assuming 110 daltons per amino acid), leaving 400 bp available either to encode a small polypeptide or for other functions. Another pNZ500 polypeptide might have gone undetected in the experiment of Fig. 5 as a result of being run off the gel or of being produced in even smaller amounts than the other pNZ500 proteins. The functions of the two polypeptides observed remain unknown, although the involvement of at least one of them in mobilization is a strong possibility since there is evidence (Warren et al., 1979) that ColE1 encodes gene products involved in its mobilization. If either of the polypeptides is required for replication it is unlikely to be the $24 \cdot 5 \mathrm{~K}$ one, since Tn 3 insertion in pNZ503 leaves a viable plasmid while abolishing production of the polypeptide. The possibility that this Tn 3 insertion alters the copy number or stability of pNZ500 has not been investigated. 
We have not been able to discern any property which $E$. coli exhibits as a result of harbouring pNZ500. Certain obvious phenotypes have not been tested, including colonization factor antigens and serum resistance. However, plasmids known to be responsible for these phenotypes are larger than pNZ500 (Taylor \& Hughes, 1978; van Embden et al., 1980 a; Penaranda et al., 1980; Stieglitz et al., 1980; Silver et al., 1981; Faris et al., 1981). Furthermore, Kopecko et al. (1980) showed that a $120 \mathrm{MDal}$ plasmid is at least partly responsible for the production of a major surface antigen in certain $S$. sonnei strains. The possibility that plasmid-coded genes are expressed in Shigella but not in E. coli appears to be unlikely in view of the close relationship between the two bacterial genera. It is possible that certain observable cell characteristics of importance to bacteria in their natural intestinal habitat result only from the expression of genes carried by more than one replicon, and that any one of the plasmids in isolation has little or no effect on its host cell.

A further possibility is that pNZ500 is of no importance to its host cell in any environment, and that it represents an efficient, minimally-encumbered plasmid replicon possessing functions only to ensure its own replication and to facilitate its transmission to other cells.

We thank Dr K. Bettelheim for performing enterotoxin assays. This work is a partial fulfilment of the requirements for the M.Sc. degree for one of the authors (J. Croft).

This work was supported by the Medical Research Council of New Zealand and the University of Auckland Research Grants Committee.

\section{REFERENCES}

Bergquist, P. L. \& Adelberg, E. A. (1972). Abnormal excision and transfer of chromosomal segments by a strain of Escherichia coli K-12. Journal of Bacteriolog! 111, 119-128

Bergquist, P. L., Downard, R. A., Caughey, P. A., Gardner, R. C. \& Lane. H. E. D. (1981). Analysis of mini-F plasmid replication by transposition mutagenesis. Journal of Bacteriology 147, 888-899.

Bergquist, P. L., Lane, H. E. D., Malcolm, L. \& Downard, R. A. (1982). Molecular homology and incompatibility in the IncFI plasmid group. Journal of General Microbiology 128, 223-238

BIRD, R. E. (1981). Homology between Escherichia coli plasmids ColE1 and p15A. Journal of Bacteriology 145, 1305-1309.

Bolivar, F. (1978). Construction and characterization of new cloning vehicles. III. Derivatives of plasmid pBR322 carrying unique EcoRi sites for selection of EcoRI generated recombinant DNA molecules. Gene 4. $121-136$

Bolivar, F., Rodriguez, R. L., Green, P. J., Betlach, M. C., Heyneker, H. L. \& Boyer, H. W. (1977). Construction and characterization of new cloning vehicles. II. A multipurpose cloning system. Gene 2, 95 113 .

BONNER, W. M. \& LASKey, R. A. (1974). A film detection method for tritium-labelled proteins and nucleic acids in polyacrylamide gels. European Journal of Biochemistry 46, 83-88.

BroOME-SMith, J. (1980). Rec $A$-independent sitespecific recombination between ColEl or ColK and a miniplasmid they complement for mobilization and relaxation: implication for the mechanism of DNA transfer during mobilization. Plasmid 4, 5163

Chang, A. C. Y. \& Cohen, S. N. (1978). Construction and characterization of amplifiable multicopy DNA cloning vehicles derived from the $15 \mathrm{~A}$ cryptic miniplasmid. Journal of Bacteriology 134, 1141-1156.

Christiansen, C., Christiansen, G., Bak, A. L. \&
Stenderup, A. (1973). Extrachromosomal deoxyribonucleic acid in different enterobacteria. Journal of Bacteriology 114, 367-377.

Clewell, D. B. (1972). Nature of ColEl plasmid replication in $E$. coli in the presence of chloramphenicol. Journal of Bacteriology 110, 667-676.

Covarrubias, L., Cervantes, L., Covarrubias, A., Soberón, S., Vichido, I., Blanco, A., KuperszTOCH-PORTNOY, Y. M. \& Bolivar, F. (1981). Construction and characterization of new cloning vehicles. V. Mobilization and coding properties of pBR322 and several deletion derivatives including pBR327 and pBR328. Gene 13, 25-35.

Cozzarelli, N. R., Kelly, R. B. \& Kornberg, A. (1968). A minute circular DNA from Escherichia coli 15. Proceedings of the National Academy of Sciences of the United States of America 60, 992-999.

Datta, N., Hughes, V. N., Nugent, M. E. \& Richards, H. (1979). Plasmids and transposons and their stability and mutability in bacteria isolated during an outbreak of hospital infection. Plasmid $\mathbf{2}$, $182-196$.

van Embden, J. D. A., de Graff, F. K., Scholls, L. M. \& Teppema, J. S. $(1980 a)$. Cloning and expression of a deoxyribonucleic acid fragment that encodes the adhesive antigen $\mathrm{K} 99$. Infection and Immunity 29, 1125-1133.

van Embden, J. D. A., van Klingeren, B., DessensKroon, M. \& Wijngaarden, L. J. (1980 b). Penicillinase-producing Neisseria gonorrhoeae in the Netherlands: epidemiology and genetic and molecular characterization of their plasmids. Antimicrobial Agents and Chemotherapy 18, 789-797.

Faris, A., Wadstrom, T. \& Frear, J. H. (1981). Hydrophobic adsorptive and haemagglutinating properties of Escherichia coli possessing colonization factor antigens (CFA/I or CFA/II), type I pili or other pili. Current Microbiology 5, 67-72.

Gardner, R. C. Caughey, P. A., Lane, H. E. D. \& BERgQuist, P. L. (1980). Replication mutants of the 
F-plasmid Escherichia coli II. Cloned replication regions of temperature sensitive mutants. Plasmid 3, 179-192.

González, J. M., Jr \& Carlton, B. C. (1980). Patterns of plasmid DNA in crystalliferous and acrystalliferous strains of Bacillus thuringiensis. Plasmid 3, 92-98.

Greene, P. J., Heyneker, H. L., Bolivar, F., Rodriguez, R. L.. Betlach, M. C., Covarrubias, A. A., Backman, K., Russel, D. J., Tait, R. \& BOYER, H. W. (1978). A general method for the purification of restriction enzymes. Nucleic Acids Research 5, 2373-2380.

Jamieson, A. F., Bremner, D. A., Bergquist, P. L. \& LANE. H. E. D. (1979). Characterization of plasmids from antibiotic resistant Shigella isolates by agarose gel electrophoresis. Journal of General Microbiology 113, 73-81.

JANSZ, H. S., ZANDBERG, J., VAN DE POL, J. H. \& VAN Bruggen, E. F. J. (1969). Circular DNA from Shigella paradysenteriae. European Journal of Biochemistry 9, 156-159.

Konowalchuk, J., Speirs, J. I. \& Stavric, S. (1977). Vero response to a cytotoxin of Escherichia coli. Infection and Immunity 18, 775-779.

KOPECKO, D. J., WASHINGTON, O. \& Formal, S. B. (1980). Genetic and physical evidence for plasmid control of Shigella sonnei form I cell surface antigen. Infection and Immunity 29, 207-214.

Kretschmer, P. J. \& Cohen, S. N. (1979). Effect of temperature on translocation frequency of the $\operatorname{Tn} 3$ element. Journal of Bacteriology 139, 515-519.

Kretschmer, P. J., Chang, A. C. Y. \& Cohen, S. N. (1975). Indirect selection of bacterial plasmids lacking identifiabie phenotypic properties. Journal of Bacteriology 124, 225-231.

Lane, H. E. D. \& Gardner, R. C. (1979). Second $E c o R I$ fragment of $\mathrm{F}$ capable of self-replication. Journal of Bacteriology 139, 141-151.

LANGRidge, J., LANGRIDGe, P. \& Bergquist, P. L. (1980). Extraction of nucleic acids from agarose gels. Analytical Biochemistry 103, 264-271.

LovetT, M. A. \& Helinski, D. R. (1976). Method for the isolation of the replication region of a bacterial replicon: construction of mini- $\mathrm{F}^{\prime}-\mathrm{km}$ plasmid. Journal of Bacteriologl 127, 982-989.

Llugtenberg, B., Meijers, J., Peters, R., van der HoCk. P. \& VAN ALPHEN, L. (1975). Electrophoretic resolution of the 'major outer membrane protein' of Escherichia coli $\mathrm{K} 12$ into four bands. FEBS Letters 58, 254-258.

MANN, M. B. \& RAO, R. N. (1979). Characterization of plasmids from Haemophilus parainfluenzae and Haemophilus haemolyticus. Plasmid 2, 503506.

Mayer. L. W., Holmes, K. K. \& Falkow, S. (1974). Characterization of plasmid deoxyribonucleic acid from Neisseria gonorrhoeae. Infection and Immunity 10, $712-717$.

MEACOCK. P. A. \& COHEN, S. N. (1980). Partitioning of bacterial plasmids during cell division: a cis-acting locus that accomplishes stable plasmid inheritance. Cell 20, 529-542.

Moller, J. K., Jorgensen, N. H. F., Christiansen, C. Christiansen, G., Bak. A. L. \& Stenderlip, A. (1978). Characterization of plasmids from wild-type Enterohacteriaceae. In Microbiology-1978, pp. 257
261. Edited by D. Schlessinger. Washington, D. C.: American Society for Microbiology.

Oka, A., Nomura, N., Morita, M., Sugisaki, G., Sugimoto, K. \& Takanami, M. (1979). Nucleotide sequence of small ColEl derivatives: structure of the regions essential for autonomous replication and colicin El immunity. Molecular and General Genetics 172, 151-159.

Penaranda, M. E., Mann, M. B., Evans, D. G. \& Evans, D. J., JR (1980). Transfer of an ST: LT:CFA/II plasmid into Escherichia coli $\mathrm{K} 12$ strain RRl by cotransformation with $\mathrm{pSC} 301$ plasmid DNA. FEMS Microbiology Letters 8, 251-254.

Rigby, P. W. J., Dieckmann, M., Rhodes, C. \& Berg, P. (1977). Labelling deoxyribonucleic acid to high specific activity in vitro by nick translation with DNA polymerase I. Journal of Molecular Biology 113, 237-251.

Roozen, K. J., Fenwick, R. G., JR \& Curtisss III, R. (1971). Synthesis of ribonucleic acid and protein in plasmid-containing minicells of Escherichia coli K 12 . Journal of Bacteriology 107, 21-33.

Rush, M. G., Gordon, C. N. \& Warner, R. C. (1969). Circular deoxyribonucleic acid from Shigella dysenteriae Y6R. Journal of Bacteriology 100, 803-808.

Silver, R. P., FinN, C. W., VANN, W. F., Aaronson, N., Schneerson, R., Kretschmer, P. J. \& Garon, C. F. (1981). Molecular cloning of the K 1 capsular polysaccharide genes of E. coli. Nature, London 289 , 686-698.

Smith, H. O. \& Birnstiel, M. L. (1976). A simple method for DNA restriction site mapping. Nucleic Acids Research 3, 2387-2398.

Smith, H. W. \& Parsell, Z. (1975). Transmissible substrate utilizing ability in enterobacteria. Journal of General Microbiology 87, 129-140.

Spratt, B. C.. Rowbury, R. J. \& Meynell, G. G. (1973). The plasmid of Salmonella tvphimurium LT2. Molecular and General Genetics 121, 347-353.

Stahly, D. P., Dingman, D. W., Irgens, R. L., Field, C. C., Feiss, M. G. \& SMith, G. L. (1978). Multiple extrachromosomal deoxyribonucleic acid molecules in Bacillus thuringiensis. FEMS Microbiology Letters 3. 139-141

Stieglitz, H., Fonseca, R., Olarte, J. \& KuperszTOCH-PORTNOY, Y. M. (1980). Linkage of heat-stable enterotoxin activity and ampicillin resistance in a plasmid isolated from an Escherichia coli strain of human origin. Infection and Immunity 30, 617620.

Sutcliffe, J. G. (1978). pBR322 restriction map derived from the DNA sequence: accurate DNA size markers up to 4361 nucleotide pairs long. Nucleic Acids Research 5, 2721-2729.

TAYLOR, P. N. \& Hughes, C. (1978). Plasmid carriage and the serum sensitivity of Enterobacteria. Infection and Immunity 22, 10-17.

WAHL. G. M., STERn, M. \& Stark, G. (1979). Efficient transfer of large DNA fragments from agarose gels to diazobenzyloxymethyl paper and rapid hybridization using dextran sulphate. Proceedings of the National Academy of Sciences of the United States of America 76. 3683-3687.

Warren, G. J., Saul, M. W. \& Sherratt, D. J. (1979). ColEl plasmid mobility: essential and conditional functions. Molecular and General Genetics 170, 103107. 